\author{
Contents list available at Multidisciplinary Journal website \\ Multidisciplinary Journal \\ Journal homepage: https://jurnal.unej.ac.id/index.php/multijournal
}

\title{
Studi Environmental Health Risk Assessment (EHRA) Faktor yang Mendorong Perilaku Penggunaan Jamban Di Kabupaten Bondowoso Tahun 2018
}

\author{
Reinforcing Factor of Lavatory Usage Behavior \\ Environmental Health Risk Assessment (EHRA) \\ In Bondowoso Regency 2018 \\ Wulandari ${ }^{*}, 1$, Fx.Ady Soesetyo ${ }^{2}$, Ancah Caesarina Novi $\mathrm{M}^{3}$

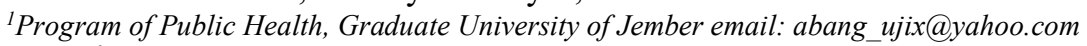 \\ ${ }^{2}$ Faculty of Dentistry, University of Jember, email: adysoesetijo@ymail.com \\ ${ }^{3}$ Medicine Faculty,University of Jember email: ancah@unej.ac.id \\ Email*: abang_ujix@yahoo.com
}

\begin{abstract}
In Indonesia the problem of sanitation is the problem of socio-cultural challenges. This also affected Bondowoso District which was in the first position of 38 Regencies or cities in East Java. So that the aim of the researcher is to describe and analyze the encouraging factors mainly focused on the role of health workers and the sanitation policy system. This study used a cross sectional design. The research location in Bondowoso Regency in November 2018. The population is 430 respondents spread across 7 sub districts. The result this study are the role of health workers with a significance value of 0,030 smaller than $\alpha$. The sanitation policy system has significance value of 0,045 smaller than $\alpha$. So, the conclution is the role of health workers and the sanitation policy system has to do with the behavior of using lavatory.
\end{abstract}

Keywords: reinforcing factor, sanitation, role of health workers, the sanitation policy system.

ABSTRAK. Di Indonesia permasalahan sanitasi adalah permasalahan tantangan sosial budaya. Hal itu juga berimbas pada Kabupaten Bondowoso yang berada pada posisi pertama dari 38 Kabupaten atau kota di Jawa Timur. Sehingga tujuan peneliti yaitu ingin mendeskripsikan serta menganalisis faktor yang mendorong terutama dititik beratkan pada peran petugas kesehatan dan sistem kebijakan sanitasi. Penelitian ini menggunakan desain cross sectional. Tempat penelitian yaitu Kabupaten Bondowoso pada bulan November 2018. Populasinya yaitu sebanyak 430 responden yang tersebar di 7 kecamatan. Hasil dari penelitian ini yaitu peran petugas kesehatan nilai signifikansinya 0,030 lebih kecil dari $\alpha$. Sistem kebijakan sanitasi nilai signifikansinya 0.045 lebih kecil dari $\alpha$. Sehingga kesimpulannya peran petugas kesehatan dan sistem kebijakan sanitasi memiliki hubungan dengan perilaku penggunaan jamban.

Kata Kunci: Faktor pendorong, sanitasi, peran petugas kesehatan, sistem kebijakan sanitasi.

\section{Pendahuluan}

Di Indonesia permasalahan sanitasi merupakan permasalahan tantangan sosial budaya. Di dalam permaslahan tersebut terdapat perilaku masyarakat yang menyimpang yaitu pola kebiasaan BAB di sembarang tempat. Menurut WHO ada skitar 2,5 miliar orang di dunia tidak memiliki akses ke fasilitas sanitasi yang layak. Di Indonesia sendiri menduduki peringkat kedua setalah India dengan tingginya masyarakat yang masih BAB sembarangan. Data juga mengatakan bahwa Jawa Timur masuk peringkat kedua setelah Jawa Tengah dengan angka BABs 824.675. Di Bondowoso hal yang memprihatinkan tersebut juga sama sehingga menjadikan Kabupaten Bondowoso peringkat pertama dari 38 Kabupaten atau kota di Jawa Timur dengan penduduk yang buang air besar sembarangan yang masih sangat tinggi yaitu sebanyak 110 ribu lebih (55,99\%). Tingginya permasalahan tersbut tak lain karena kesadaran indivudu yang kurang akan pentingnya menerapkan perilaku hidup bersih dan sehat salah satunya tidak buang air besar di sembarang tempat. Kesadaran masyarakat tersebut dibentuk dari kebiasaan dimana kebiasaan tersebut dipengaruhi oleh faktor- faktor yang membentuk perilaku yaitu faktor yang mendorong yang berfokus atau dititik beratkan pada peran petugas kesehatan dan sistem kebijakan sanitasi. Mengingat kebiasaan 
masyarakat sulit sekali dirubah karena sudah diwariskan maka perlu dicari solusi untuk merubah pola kebiasaan tersebut. Berdasarkan data dan pemaparan di atas peneliti tertarik untuk melakukan penelitian mengenai faktor yang mendorong yang berhubungan dengan perilaku penggunaan jamban di Kabupaten Bondowoso.

Perilaku merupakan respon terhadap individu yang berasal dari luar yang berupa stimulus.1 Berdasarkan hasil analisis dari Green (1980) tentang tingkat kesehatan individu yaitu ada 3 faktor yang berperan meliputi faktor yang mempermudah yang timbul dengan sendirinya dari dalam diri individu berupa umur, pendidikan, pengetahuan, jenis kelamin, status ekonomi, nilai dan persepsi serta jumlah keluarga. Faktor pemungkin atau enabling factor merupakan faktor yang memudahkan individu atau kelompok untuk merubah perilaku di lingkungan mereka tinggal. Bentuk dari faktor pemungkin ini yaitu pekerjaan, ketersedian air bersih, kepemilikan jamban, jarak jamban ke sumber air, luas lahan, dan peran serta responden. Sedangaka faktor yang mendorong adalah faktor yang ikut memberikan andil terjadinya perubahan perilaku di masyarakat, hal ini dapat berupa peran petugas kesehatan, sistem kebijakan sanitasi serta dukungan dari keluarga, tokoh masyarakat maupun tokoh agama.

Tujuan dari penelitian ini yaitu mendeskripsikan dan menganalisis faktor yang mendorong atau reinforcing factor berupa peran petugas kesehatan dan sistem kebijakan sanitasi.

\section{Bahan dan Metode}

Penelitian ini menggunakan jenis penelitian analitik obervasional dengan desain penelitian cross sectional. Populasi penelitian ini yaitu masyarakat yang berdomisi di Kabupaten Bondowoso. Sampel penelitian ini yaitu masyarakat yang ada di 7 kecamatan (Kecamatan Tamanan, Tenggarang, Tapen, Sempol, Tlogosari, Taman Krocok dan Tegal Ampel dengan total jumlah 430 responden. Tempat penelian ini yaitu di Kabupaten Bondowoso yang dilakukan pada bulan November 2018.

\section{Hasil dan Pembahasan}

Hasil tabulasi silang antara peran petugas kesehatan dengan perilaku penggunaan jamban didapatkan hasil bahwa mayoritas responden penelitian menilai peran kesehatan mendukung dengan tingkat perilaku penggunaan jamban dengan kategori kurang yaitu sebesar 34,9\% (150 responden). Nilai signifikansi 0,030 lebih kecil dari $\alpha(0,05)$, yang menunjukkan hubungan yang bermakna antara peran petugas kesehatan dangan perilaku penggunaan jamban.
Tabel 1. Hubungan Peran Petugas Kesehatan dengan Perilaku Penggunaan Jamban

\begin{tabular}{lcccc}
\hline Peran Petugas & \multicolumn{4}{c}{ Perilaku } \\
\cline { 2 - 5 } Kesehatan & Kurang & Persen & Baik & Persen \\
\hline Tidak & 146 & 34,0 & 51 & 11,9 \\
mendukung & & & & \\
Mendukung & 150 & 34,9 & 83 & 19,3 \\
Total & 296 & 68,8 & 134 & 31,2 \\
Nilai & 0,030 lebih kecil dari $\alpha$ & $(0,05)$ \\
signifikansi & \multicolumn{4}{c}{} \\
\hline
\end{tabular}

Hasil tabulasi silang sistem kebijakan sanitasi dan perilaku penggunaan jamban diperoleh bahwa mayoritas responden penelitian menilai terdapat kebijakan sistem sanitasi dengan tingkat perilaku penggunaan jamban dengan kategori kurang yaitu sebesar 38,1\% (164 responden). Nilai signifikansi 0,045 lebih kecil dari $\alpha(0,05)$ yang menunjukkan hubungan yang bermakna antara sistem kebijakan sanitasi dengan perilaku penggunaan jamban.

Tabel 2. Hubungan Sistem Kebijakan Sanitasi dengan Perilaku Penggunaan Jamban

\begin{tabular}{lcccc}
\hline Sistem Kebijkan & \multicolumn{4}{c}{ Perilaku } \\
\cline { 2 - 5 } Sanitasi & Kurang & Persen & Baik & Persen \\
\hline Tidak ada & 132 & 30,7 & 46 & 10,7 \\
Ada & 164 & 38,1 & 88 & 20,5 \\
Total & 296 & 68,8 & 134 & 31,2 \\
Nilai signifikansi & 0,171 lebih besar dari $\alpha$ & $(0,05)$ \\
\hline
\end{tabular}

Peran petugas kesehatan berpengaruh pada perilaku penggunaan jamban. Hal ini sejalan dengan penelitian Saut Hasudungan (2013) yang menyatakan ada hubungan antara peran petugas kesehatan dengan perilaku penggunaan jamban. ${ }^{2}$ Peran petugas tersebut terwujud di dalam pemberian motivasi dan penggerak di masyarakat. Tugas dan tanggung jawab petugas kesehatan adalah memberikan edukasi kesehatan yang terwujud dalam bentuk penyuluhan dan pemberian fasilitas untuk memelihara kesehatannya. ${ }^{3}$ Hasil penelitin ini juga memiliki kesamaan dengan penelitian yang dilakukan Erlinawati (2009) yang menyatakan ada hubungan yang bermakna antara pembinaan penggunaan jamban oleh petugas puskesmas dengan perilaku keluarga dalam menggunakan jamban. ${ }^{4}$

I Nengeh Darsana (2012) menyatakan bentuk peran petugas dapat berupa pemberian motivasi, bimbingan teknis, penggerakan, pemberdayaan maupun penyuluhan dari para petugas kesehatan tersebut yang juga dibantu oleh para kader, dengan harapan petugas kesehatan dapat merubah kebiasaan buruk masyarakat dengan cara menumbuhkan serta meningkatkan pengetahuan dan kesadaran mereka dalam berperilaku hidup bersih dan sehat.

Sebagian besar responden mengatakan ada peran petugas dalam upaya pemanfaatan jamban di masyarakat namun menurut temuan di lapangan adanya penyuluhan tentang pemanfaatan jamban ataupun stimulant pengadaan jamban sedikit terhambat mengingat karakteristik masyarakat yang beragam mulai dari tradisi serta adat kebiasaan mereka dalam pemanfaatan jamban. Banyak masyarakat yang sudah pola BABnya terlanjur di sembarang tempat karena terlalu lamanya kebiasaan tersebut. Sehingga segencar apupun petugas kesehatan memberikan arahan dan 
penyuluhan tidak semua masyarakat dapat menerapkan atau mengaplikasikan himbauan tersebut. Hasil penelitian menyebutkan ada hubungan antara sistem kebijakan sanitasi dengan perilaku penggunaan jamban. Dengan adanya kebijakan dari pemerintah masyarakat menjadi sadar untuk menggunakan jamban sebagai sarana BAB.

Pengendalian atau pengelolaan lingkungan yang baik, dalam hal ini sanitasi maka peningkatan harkat dan kesejahteraan masyarakat dapat dicapai, serta kualitas lingkungan tetap terpelihara. Implementasi Program Gerakan Sanitasi Berbasis Masyarakat dalam pengendalian lingkungan berupaya untuk menanggulangi masalah sanitasi yang berdampak buruk terhadap lingkungan yang belum berjalan dengan baik, maupun permasalahan sanitasi yang kurang tepat. ${ }^{5}$ Adapun beberapa programkesehatan lingkungan dari puskesmas maupun dinas Kesehatan Kabupaten Bondowoso yang dijalankan serta berhubungan dengan penelitian ini, antara lain:

1. Program Gebyar Desa ODF

Program Gebyar Desa ODF adalah program dari kota dalamhal ini adalah Dinas Kesehatan Kabupaten Bondowoso untuk mewujudkan Bondowoso benar-benar bebas buang air besar sembarangan. Program ini didukungoleh pemerintah daerah dan desa guna mewujudkan Bondowoso bebas buang air besar sembarangan. Tercatat pada Tahun 2018 ada 22 desa yang dikatakan desa ODF

2. Uapaya Simulan Pembanguna Jamban (Gesit)

Adanya program Gerakan Sanitasi Total (Gesit) yang dilakukan oleh Dinas Kesehatan Kabupaten Bondowoso yang berwujud upaya stimulan pembangunan jamban diadakan di 10 Kecamatan (114 Desa ) salah satunya yang diikuti peneliti adalah upaya stimulan pembangunan jamban di Kecamatan Tlogosari, sebanyak 100 Jamban. program ini di tanda tangani langsung oleh puskesmas serta bekerja sama dengan perangkat desa yang nantinya menjadi desa yang akan distimulan.

3. Kampenya Perilaku Hidup Bersih dan Sehat (PHBS) dengan sasaran rumah tangga, pendidikan, serta institusi dunia kesehatan.

Dari data tersebut peneliti beranggapan program yang dijalankan oleh petugas kesehatan sudah cukup baik, namun dalam implementasinya belum dilakukan secara optimal oleh petugas kesehatan, selain itu jika dilihat dari segi masyarakatnya kecendrungan untuk berprilaku hidup bersih dan sehat (PHBS) masih cukup rendah, selain itu cara berpikir masyarakat yang masih kurang dalam pemahaman akan pentingnya menjaga kesehatan, masyarakat merasa diuntungkan dengan melakukan BABs di sungai karena tidak mengotori dan menimbulkan bau dirumah mereka.

4. Program Penyediaan Air Minum dan Sanitasi Berbasis Masyarakat (PAMSIMAS)
Penyedian air minum dan sanitasi Berbasis masyarakat tersebut dipelopori oleh PU pengairan dalam hal ini kegiatan yang dilakukan yaitu penyediaan air bersih dan juga menangani masalah-masalah terkait sanitasi termasik di dalamnya jamban.

5. Sanitasi Berbasis Masyarakat (SANIMAS)

SANIMAS adalah program yang diadakan oleh PU pemukiman yang didalamnya terdapat kegiatan pembangunan jamban komunal atau jamban umum yang digunakan bersama-sama oleh masyarakat terutama di daerah tertinggal.

Berdasarkan temuan di lapangan banyaknya program yang telah dilakukan pemerintah atupun pihakpihak terkait untu merubah pola sanitasi masyarakat agar semakin baik, tentunya memiliki berbagai macam hambatan, hambatan yang sangat sulit sekali ditangani yaitu kebiasaan masyarakat tentang pola perilaku BABs yang sudah turun temurun sulit untuk dihilagkan, selain itu bantuan yang diberikan berupa fasilitas kesehatan dalam hal ini jamban jamban juga kurang dirawat bahkan banyak fasilitas tersebut terbengkalai dan tidak digunakan.

\section{Kesimpulan}

Pada faktor yang mendorong (reinforcing factor) yaitu peran petugas kesehatan mendukung serta terdapat sistem kebijakan sanitasi. Ada hubungan antara peran petugas kesehatan dengan prilaku penggunaan jamban. Terdapat hubungan antara sistem kebijakan sanitasi dengan prilaku penggunaan jamban.

\section{Ucapan Terimakasih}

Ucapan terimakasih peneliti kepada semua pihak yang telah membantu serta ikut andil dalam penyelesaian tesis ini yaitu dosen, teman seangkatan dan keluarga tercinta.

\section{Referensi}

[1] Notoatmodjo, S. Pengembangan Sumber Daya Manusia. Edisi Revisi, Cetakan Ketiga: Jakarta : Penerbit PT. Rineka Cipta;2003

[2] STBM. 2009. Pe laksaan Sanitasi Total Berbasis Masyarakat dalam Program PAMSIMAS (juli 2018) http://www.esp.or.id/stbm.

[3] Azwar A. 2005. Pengantar Ilmu Kesehatan Lingkungan: Jakarta: Mutiara Sumber Widya Press.

[4] Irawati D, Faktor-Faktor Karekteristik yang Berpengaruh Terhadap Pelaksanaan Perilaku Hidup Bersih dan Sehat di Desa Tangunan Kecamatan Puri Kabupaten Mojokerto. Jurnal Ilmiah Kesehatan Politeknik Kesehatan Majapahit; 2013. (diakses pada Juli 2018).

[5] Candra B. 2007. Pengantar Kesehatan Lingkungan. Jakarta: Penerbit Buku Kedokteran EGC. 